\title{
Estimation of Magnitude of Heterosis and Heritability in Sunflower in 8X8 Half Diallel Population
}

\author{
M. H. Rashid \\ Senior Scientific Officer, Oilseed Research Center, Bangladesh Agricultural Research \\ Institute, Gazipur 1701, E-mail: harunorc_bari@yahoo.com, +8801716517314
}

\begin{abstract}
A. K. M. Aminul Islam
Professors, Department of Genetics and Plant Breeding, Banghabandhu Sheikh Mujibur Rahman Agricultural University, Gazipur 1706, E-mail: aminulgpb@bsmrau.edu.bd, pulak292003@yahoo.com
\end{abstract}

M. G. Rasul

Professors, Department of Genetics and Plant Breeding, Banghabandhu Sheikh Mujibur Rahman Agricultural University, Gazipur 1706, E-mail: mdgolam60@yahoo.com $+8801715401448$

M. M. H. Saikat

Professors, Department of Genetics and Plant Breeding, Banghabandhu Sheikh Mujibur Rahman Agricultural University, Gazipur 1706, E-mail: saikathu@yahoo.com $+8801552495428$

\section{J. U. Ahmed}

Professors, Department of Genetics and Plant Breeding, Banghabandhu Sheikh Mujibur Rahman Agricultural University, Gazipur 1706, E-mail: jahmed06@gmail.com $+8801710838890$

Received: December 3, 2020

doi:10.5296/jas.v9i1.18026
Accepted: January 21, 2021 Published: February 19, 2021

URL: https://doi.org/10.5296/jas.v9i1.18026 


\section{Abstract}

Selected eight inbreed line were used in crossing as half diallel fashion to find out different genetic parameter as well as targeting superior combination for hybrid vigour. Sunflower first introduce in Bangladesh 1980 by Bangladesh Agricultural Research Institute and Mennonite Central Committee. BARI Sunflower-1(Kironi) and BARI Sunflower-2 is only two released variety. But major obstacles for sunflower cultivation are both varieties are more than $1.50 \mathrm{~m}$ height and require > 100 days for maturity. As this country is facing climate change unfavorable weather, sunflower cannot withstand in stormy weather. Specially at the time of prematurity stormy weather causes lodging due to over height, it is essential to develop dwarf stature plant. Due to strong crop competition in winter it cannot fit in major cropping pattern T-Aman-Mustard-Boro due to it long duration. Bangladesh has accessible land of 0.85 million hectares in saline areas (Banik et al., 2011). These lands can be used for sunflower cultivation as it is moderately saline tolerant (Rahman et. al. 2018). On the other hand in different part of Bangladesh (e.g. Cumilla, Manikgonj, Sherpur, Jamalpur, Netrokina, Tangail, Dinajpur, etc.), a huge amount of lands are kept fellow after T. Aman harvest. These current fellow lands can be easily used by sunflower cultivation if short duration varieties are available. Both plant height and days to maturity were considered as favorable for negative heterosis to obtain dwarf plant stature and short duration plant to fit in existing cropping pattern in Bangladesh. Positive heterosis is considered desirable for other yield contributing traits. The hybrid HE15, HE17 and HE16 showed significant negative heterosis both for mid parent and better parent. Negative heterosis for plant height is desirable to adopt hybrid in unfavorable weather condition. The Hybrid HE15 showed both for significant negative mid parent and better parent heterosis. High heritability along with significant mid parent and better parent heterosis indicate scope of utilization of hybrid as commercial and further use in breeding programmes. Several outstanding cross combinations, HE17, HE16, HE14, HE15, and HE18 showed significant and desirable heterosis for seed yield per plant over mid parent and better parent. The hybrid combinations HE17, HE16 and HE14 could be utilized to exploit the heterosis as well as commercial multiplication of seed to get direct benefit by the farmers.

Keywords: sunflower, half diallel, heterosis, heritability

\section{Introduction}

Sunflower is a member of composite family contains a typical composite flower and genus Helianthus. Helianthus consist of sixty seven species of which 17 are cultivated, others are mainly ornamental. The sunflower is originated in the southeast United States and Mexico (Heiser, 1976; Vranceaunu, 1974). The genus Helianthus are mostly found in North America, Tropical America, and few are found in Peru and Chile. The most closely related species of Helianthus annuus is considered to be Helianthus agrophyllus, native to Texas, USA (Heiser 1976). Ukraine is the top sunflower seed producing (122.35 lac ton) country in the world during 2017 (www.faostat.fao.org). Russia and Argentina secure the second and third position, respectively for seed production of sunflower. Sunflower is now widely produced in Rumania, Turkey, Bulgaria, Spain, Yugoslavia, USA, South Africa, USSR and India. 
In Bangladesh sunflower has been introduced as an oilseed crop by Bangladesh Agricultural Research Institute and Mennonite Central Committee (MCC) in 1980 (Rahman, 2009). Its production was limited to very small areas and to the experimental field during 1980s. Now it is minor oilseed crop in Bangladesh. Sunflower covers 0.019 lac hectare of land in our country are producing 0.042 lac metric ton of seed during 2017-18 (Anon., 2019a). Major sunflower growing area in Bangladesh is Faridpur, Kushtia, Barisal, Rangpur, Tangail, Patuakhali, Rajshahi, Khulna and Satkhira region. Good scope for sunflower as an oil crop exists for some areas. The cultivated area of oilseed in Bangladesh is 7.24 lac hectares, from which 9.70 lac metric ton seed is produced and 3.38 lac metric ton oil is extracted (Anon., 2019a). On the other hand, annual demand of oil is 1.32 million tons oil [ $(22 \mathrm{~g} / \mathrm{head} / \mathrm{day}$, (Mallik, 2013) 164.60 million population (Anon., 2018)]. If we analyzed annual demand and production it is found deficit of oil is $75 \%$. So Bangladesh is very deficit in vegetable oil supply. Domestic production can hardly meet $25 \%$ of the requirement. Oleiferous Brassica is the main source of domestic vegetable oil supply in Bangladesh (Mallik, 2013).

Over the past decades sunflower oil has become popular worldwide. Sunflower oil is light in taste and appearance and supplies more Vitamin E than any other vegetable oil. It is a combination of monounsaturated and polyunsaturated fats with low saturated fat levels. The oil is typically extracted by applying great pressure as like as mustard seeds and collecting the oil. The protein-rich cake remaining after the seeds have been processed for oil is used as a livestock feed.

For the development of hybrids, inbred lines are essential. The suitable inbred parents can be identified through combining ability test. The heterosis has also been recognized as one of the major land marks in crop improvement. Hence, there is a need to develop local hybrids to save the foreign exchange and also to increase the productivity. This is the need of time to produce sunflower hybrids which are well suited to local environment, have well yield potential for seed as well as oil contents. Estimation of combining abilities at both general and specific levels and manifestation of heterosis for yield components is an important criterion for obtaining productive hybrids. Sunflower is one of the important crop in which occurrence of heterosis is highly related with genetic distance between the parental lines.

\section{Material and Methods}

Twenty eight F1's were developed through crossing between eight parents following 8 × 8 half diallel fashion (Table 1). Seeds of 28 hybrids along with parents were sown during Rabi season of 2017-18 using RCBD design with three replications. The unit plot size was $4 \mathrm{~m} x$ $4 \mathrm{~m}$ with spacing $50 \mathrm{~cm} \mathrm{X} 25 \mathrm{~cm}$. 


\section{Macrothink}

Table 1 Diallel crossing scheme to develop 28 half diallel hybrids of sunflower

\begin{tabular}{|c|c|c|c|c|c|c|c|c|c|}
\hline \multirow{10}{*}{ 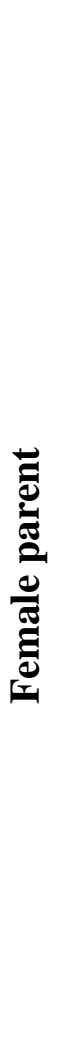 } & \multicolumn{9}{|c|}{ Male parent } \\
\hline & & P1 & $\mathrm{P} 2$ & P3 & $\mathrm{P} 4$ & P5 & P6 & P7 & P8 \\
\hline & P1 & $1 \times 1$ & $1 \times 2$ & $1 \times 3$ & $1 \times 4$ & $1 \times 5$ & $1 \times 6$ & $1 \times 7$ & $1 \times 8$ \\
\hline & $\mathrm{P} 2$ & & $2 \times 2$ & $2 \times 3$ & $2 \times 4$ & $2 \times 5$ & $2 \times 6$ & $2 \times 7$ & $2 \times 8$ \\
\hline & P3 & & & $3 \times 3$ & $3 \times 4$ & $3 \times 5$ & $3 \times 6$ & $3 \times 7$ & $3 \times 8$ \\
\hline & P4 & & & & $4 \times 4$ & $4 \times 5$ & $4 \times 6$ & $4 \times 7$ & $4 \times 8$ \\
\hline & P5 & & & & & $5 \times 5$ & $5 \times 6$ & $5 \times 7$ & $5 \times 8$ \\
\hline & P6 & & & & & & $6 \times 6$ & $6 \times 7$ & $6 \times 8$ \\
\hline & P7 & & & & & & & $7 \times 7$ & $7 \times 8$ \\
\hline & P8 & & & & & & & & $8 \times 8$ \\
\hline
\end{tabular}

Staggered sowing of selected inbreed lines was carried out three times at an interval of two days to ensure synchronization of all inbreeds. In order to prevent undesirable pollination, heads of inbreed lines were covered with cloth bags a day prior to opening of first ray floret. Cloth bags were only open when hand pollination was done. Pollen from the inbred lines was collected in petridis from which using A4 paper applied to the flowers of female lines using camel hairbrush during morning hours usually $9.30 \mathrm{am}-11.30 \mathrm{am}$.
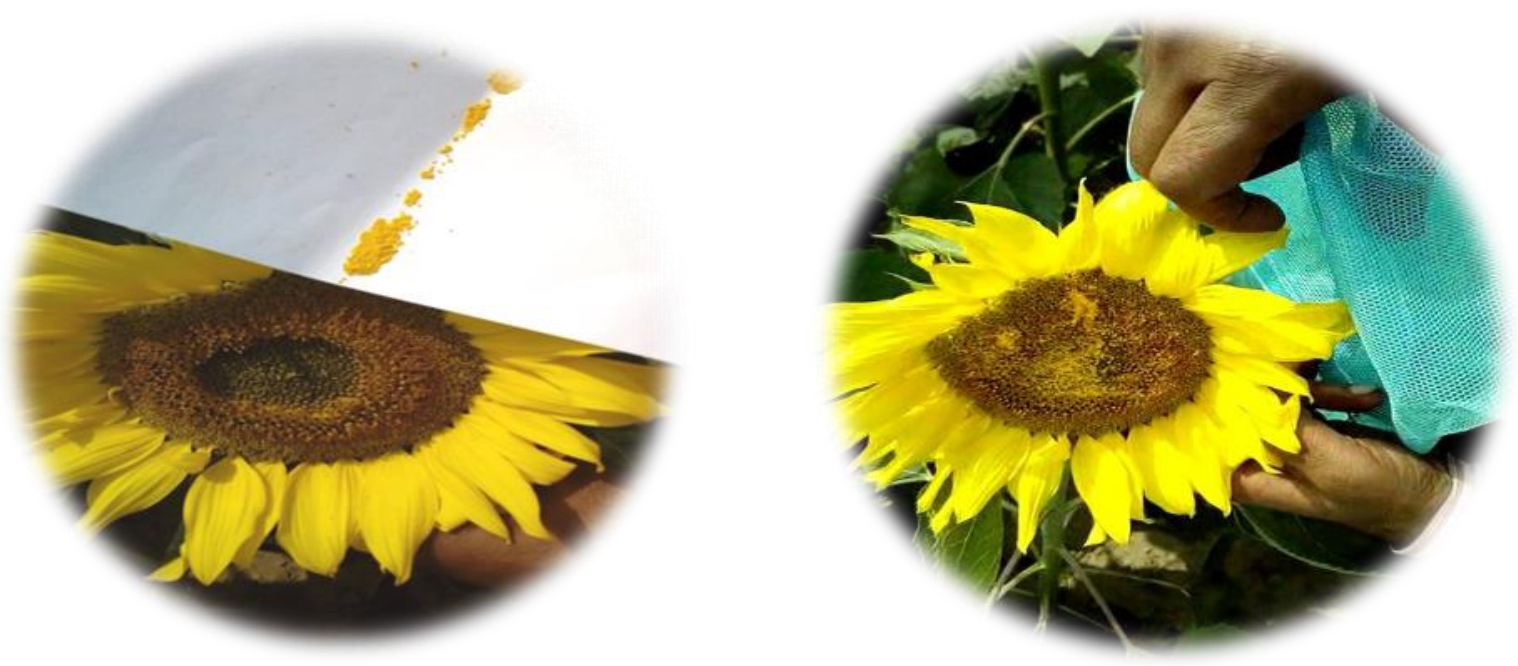
Pollen are dusting in the head of sunflower

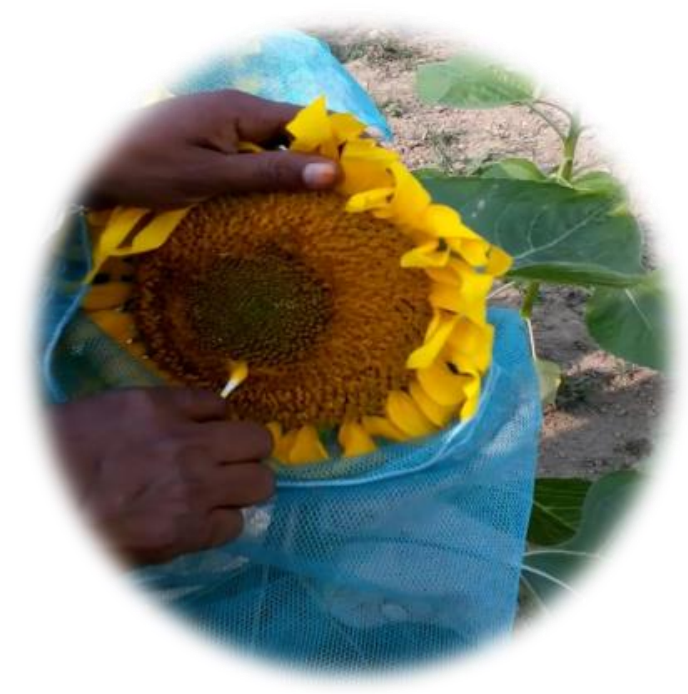

Pollen are brushing in flower of head
Dusted pollen on sunflower head

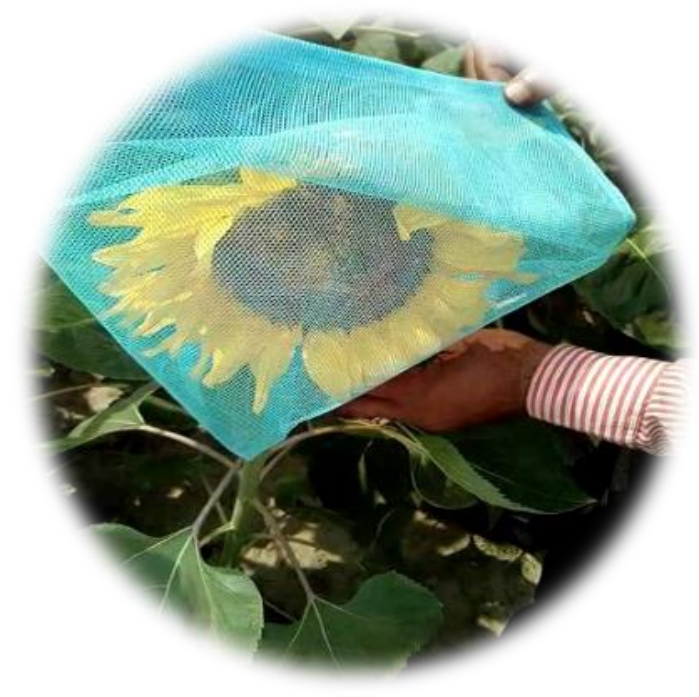

Brushed head are covering by net bag

Plate 1. Crossing technique of sunflower through hand pollination

The pollination was repeated for five to six days in each of the combination to ensure sufficient seed set and simultaneously, parental lines were maintained by self-pollination. The heads of all the resultant 28 hybrids and 8 parents were harvested, dried and threshed separately.

\section{Estimation of Heterosis}

Heterosis expressed as percent increase or decrease in hybrid vigour over its better parent (BP), mid parent (MP) values in the desirable direction estimated in terms of different parameters.

(i) Mid parent heterosis (MP)/Relative heterosis (RH) expressed as percent deviation of mean performance of F1 from mid parents value, i.e. average value of female and male parents involved. It was estimated as formula suggested by Turner (1953).

Mid parent heterosis/Relative heterosis $(\mathrm{RH})=\frac{\mathrm{F} 1-\mathrm{MP}}{\mathrm{MP}}$

$\mathrm{MP}=$ Mean value of the parents for respective hybrid

$\mathrm{F}_{1}=$ Mean performance of the hybrid $\left(\mathrm{F}_{1}\right)$.

(ii) Better parent (BP)/Heterobeltiosis (HB) expressed as percent deviation of mean performance of F1 towards better parent in respect to desired direction. It was estimated as formula suggested by Fonseca and Patterson (1968). 


$$
\begin{gathered}
\text { Better parent heterosis/Heterobeltiosis }(\mathrm{HB}) \%=\frac{\mathrm{F}_{1}-\mathrm{BP}}{\mathrm{BP}} \\
\mathrm{BP}=\text { Mean value of better parent } \\
\mathrm{F}_{1}=\text { Mean value of the hybrid }(\mathrm{F} 1) .
\end{gathered}
$$

\section{Estimation of heritability}

Broad sense habitability was estimated (defined by Lush, 1949) by the formula suggested by Hanson et al. (1956) and Johanson et al. (1955)

$$
\begin{aligned}
& \mathrm{h}_{\mathrm{b}}^{2}=\left(\sigma_{\mathrm{g}}^{2} / \sigma_{\mathrm{p}}^{2}\right) \times 100 \\
& \text { Where, } \mathrm{h}_{\mathrm{b}}^{2}=\text { Heritability in broad sense } \\
& \sigma_{\mathrm{g}}^{2}=\text { Genotypic variance } \\
& \qquad \sigma_{\mathrm{p}}^{2}=\text { Phenotypic variance }
\end{aligned}
$$

\section{Results and Discussion}

\subsection{Heterosis}

Negative heterosisis considered beneficial for days to maturity and plant height and positive heterosis is considered desirable for other yield contributing traits. Heterosis estimated over mid parent and better parent are presented in Table 3 and 4, respectively. The salient features of heterosis for different characters are described below:

\subsubsection{Days to Maturity}

Mid parent and better parent heterosis ranged from -95 (HE18) to 658 (HE3) and -97 (HE22) to 290 (HE3), respectively. Among the 28 cross combinations, significant positive heterosis for mid parent was observed in 12 crosses and eight crosses showed better parent heterosis. Both significant negative heterosis over mid parent (-95\%) and better parent (-97\%) were observed in four crosses. For days to maturity negative heterosis is desirable to get early maturing hybrid. The crosses HE18, HE15, HE17and HE16 showed significant negative heterosis over mid parent and the crosses HE15, HE17, HE16 and HE14 showed significant negative heterosis over better parent. The presence of negative heterosis for days to maturity was reported by Bharathi et al. (2007), Chavan (2013), Reddy and Nadaf (2013).

\subsubsection{Plant Height}

Variation was observed in the direction and magnitude of heterotic effects among 28 crosses for plant height. Mid parent and better parent heterosis ranged from -87 (HE19) to 95 (HE10) and -93 (HE18) to 93 (HE17), respectively for plant height (Table 2). Among the cross combination, 12 and 8 crosses recorded significant positive heterosis over mid (up to 95\%) and better parent (93\%), respectively. Among the crosses four and three crosses recorded significant negative heterosis over mid parent (-87\%) and better parent (-93\%), respectively. Negative heterosis for plant height is desirable to adopt hybrid in unfavorable weather condition. The crosses HE19, HE18 and HE17showed significant negative mid parent 
heterosis and the crosses HE18, HE16, HE15, HE14, HE22, HE23, HE27, HE24, HE21 and HE25 showed significant negative better parent heterosis. The evidence of negative heterosis for plant height is also reported by Chavan (2013), Reddy and Nadaf (2013). The cross combination HE10, HE9, HE17, HE12, HE11, HE3, HE13, HE14, HE15, HE5and HE7 showed significant positive mid parent heterosis and the crosses HE17, HE26, HE20, HE19, HE28, HE12, HE13 and HE11 showed significant positive better parent heterosis for plant height. Significant positive heterosis was also reported by Amin et al. (2014), Meena et al. (2013) in sunflower.

Table 2 Heterosis over mid parent and better parent for days to maturity, plant height, stem diameter and head diameter in sunflower

\begin{tabular}{|c|c|c|c|c|c|c|c|c|c|c|}
\hline \multirow[t]{2}{*}{$\mathrm{SN}$} & \multirow{2}{*}{\multicolumn{2}{|c|}{ Crosses }} & \multicolumn{2}{|c|}{ Days to maturity } & \multicolumn{2}{|c|}{ Plant height $(\mathrm{cm})$} & \multicolumn{2}{|c|}{ Stem diameter $(\mathrm{mm})$} & \multicolumn{2}{|c|}{ Head diameter $(\mathrm{cm})$} \\
\hline & & & $\begin{array}{c}\text { Mid } \\
\text { parent }\end{array}$ & $\begin{array}{l}\text { Better } \\
\text { parent }\end{array}$ & $\begin{array}{c}\text { Mid } \\
\text { parent }\end{array}$ & $\begin{array}{l}\text { Better } \\
\text { parent }\end{array}$ & $\begin{array}{c}\text { Mid } \\
\text { parent }\end{array}$ & $\begin{array}{l}\text { Better } \\
\text { parent }\end{array}$ & $\begin{array}{c}\text { Mid } \\
\text { parent }\end{array}$ & $\begin{array}{l}\text { Better } \\
\text { parent }\end{array}$ \\
\hline HE1 & $\begin{array}{l}\text { Entry P-S-2 } \\
\text { Entry-23 }\end{array}$ & $\mathrm{x}$ & 14.91 & -15.59 & -1.20 & -3.67 & 5.81 & -5.33 & -9.17 & -27 \\
\hline $\begin{array}{l}\mathrm{HE} \\
2\end{array}$ & $\begin{array}{l}\text { Entry P-S-2 } \\
\text { GP-04026 }\end{array}$ & $\mathrm{x}$ & $86.89 * *$ & 35.80 & -3.00 & -3.00 & 22.40 & 5.93 & 24.06 & -5.60 \\
\hline $\begin{array}{l}\mathrm{HE} \\
3\end{array}$ & $\begin{array}{l}\text { Entry P-S-2 } \\
\text { GP-01009 }\end{array}$ & $\mathrm{x}$ & $658.20 * *$ & $289.92 * *$ & $86.35^{* *}$ & -1.00 & $-73.38 * *$ & $-85.37 * *$ & -68.71 & -82.91 \\
\hline $\begin{array}{l}\mathrm{HE} \\
4\end{array}$ & $\begin{array}{l}\text { Entry P-S-2 } \\
\text { GP-01005 }\end{array}$ & $\mathrm{x}$ & $511.19 * *$ & 213.44 & $91.66^{* *}$ & 0.00 & $-74.18 * *$ & $-85.81 * *$ & -78.21 & $-88.29 *$ \\
\hline $\begin{array}{l}\mathrm{HE} \\
5\end{array}$ & $\begin{array}{l}\text { Entry P-S-2 } \\
\text { GP-01004 }\end{array}$ & $\mathrm{x}$ & $594.65 * *$ & $260.05^{* *}$ & $85.57 * *$ & -1.33 & $-75.30^{* *}$ & $-86.43 * *$ & -79.12 & $-88.72 * *$ \\
\hline $\begin{array}{l}\mathrm{HE} \\
6\end{array}$ & $\begin{array}{l}\text { Entry } \quad \text { P-S-2 } \\
\text { BHAC-04038(1) }\end{array}$ & $\mathrm{x}$ & $489.73^{* * *}$ & $207.17 * *$ & $80.09 * *$ & -3.67 & $-73.60 * *$ & $-85.50 * *$ & -73.05 & $-85.21 *$ \\
\hline $\begin{array}{l}\mathrm{HE} \\
7\end{array}$ & $\begin{array}{l}\text { Entry P-S-2 x Entr } \\
\text { no.-20 }\end{array}$ & & $426.79 * *$ & $177.71^{* *}$ & $83.93 * *$ & -0.33 & $-75.83 * *$ & $-86.68 * *$ & -73.23 & $-85.43 * *$ \\
\hline $\begin{array}{l}\mathrm{HE} \\
8\end{array}$ & $\begin{array}{l}\text { Entry-23 } \\
\text { GP-04026 }\end{array}$ & $\mathrm{x}$ & $48.41 *$ & $45.88^{*}$ & 1.88 & -0.67 & 11.28 & 7.16 & -4.09 & -10.41 \\
\hline $\begin{array}{l}\mathrm{HE} \\
9\end{array}$ & $\begin{array}{l}\text { Entry-23 } \\
\text { GP-01009 }\end{array}$ & $\mathrm{x}$ & $252.34 * *$ & 78.53 & $94.89 * *$ & 3.86 & $-76.99 * *$ & $-87.05 * *$ & -67.66 & $-81.34 *$ \\
\hline $\begin{array}{l}\mathrm{HE} \\
10\end{array}$ & $\begin{array}{l}\text { Entry-23 } \\
\text { GP-01005 }\end{array}$ & $\mathrm{x}$ & $198.46^{* * *}$ & $51.18^{*}$ & $95.27 * *$ & 2.11 & $-75.92 * *$ & $-86.44 * *$ & -73.93 & $-85.21 * *$ \\
\hline $\begin{array}{l}\mathrm{HE} \\
11\end{array}$ & $\begin{array}{l}\text { Entry-23 } \\
\text { GP-01004 }\end{array}$ & $\mathrm{x}$ & $239.46^{* *}$ & $72.65 * *$ & $89.47 * *$ & $1.05^{* * *}$ & $-70.13 * *$ & $-83.20 * *$ & -73.38 & $-84.92 * *$ \\
\hline $\begin{array}{l}\mathrm{HE} \\
12\end{array}$ & $\begin{array}{l}\text { Entry-23 } \\
\text { BHAC-04038(1) }\end{array}$ & $\mathrm{x}$ & $205.78 * *$ & $55.88^{*}$ & $90.88 * *$ & $2.46^{* * *}$ & $-77.96^{* *}$ & $-87.60 * *$ & -74.02 & $-84.90 *$ \\
\hline $\begin{array}{l}\mathrm{HE} \\
13\end{array}$ & $\begin{array}{l}\text { Entry-23 x Entr } \\
\text { no.-20 }\end{array}$ & & $149.52^{* * *}$ & 27.94 & $85.73 * *$ & $1.05 * *$ & $-74.27 * *$ & $-85.47 * *$ & -76.62 & $-86.58 * *$ \\
\hline $\begin{array}{l}\mathrm{HE} \\
14\end{array}$ & $\begin{array}{l}\text { GP-04026 } \\
\text { GP-01009 }\end{array}$ & $\mathrm{x}$ & -50.71 & $-75.04 * *$ & $85.73 * *$ & $-62.77 * *$ & $22.30 *$ & $-30.54 * *$ & 5.63 & -37.82 \\
\hline $\begin{array}{l}\mathrm{HE} \\
15\end{array}$ & $\begin{array}{l}\text { GP-04026 } \\
\text { GP-01005 }\end{array}$ & $\mathrm{x}$ & $-95.01 *$ & $-97.48 * *$ & $85.73 * *$ & $-92.22 * *$ & $74.89 * *$ & -0.67 & $170.65^{* * *}$ & $56.30 *$ \\
\hline $\begin{array}{l}\mathrm{HE} \\
16\end{array}$ & $\begin{array}{l}\text { GP-04026 } \\
\text { GP-01004 }\end{array}$ & $\mathrm{x}$ & $-94.20 *$ & $-97.05^{* *}$ & -85.09 & $-92.55 * *$ & $75.62 * *$ & -0.33 & $199.59^{* *}$ & $72.74 *$ \\
\hline $\begin{array}{l}\mathrm{HE} \\
17\end{array}$ & $\begin{array}{l}\text { GP-04026 } \\
\text { BHAC-04038(1) }\end{array}$ & $\mathrm{x}$ & $-94.93 *$ & $-97.42 * *$ & $-85.98 * *$ & $92.79 * *$ & $76.21 * *$ & 3.46 & $253.59^{* * *}$ & $109.82 * *$ \\
\hline $\begin{array}{l}\mathrm{HE} \\
18\end{array}$ & $\begin{array}{l}\text { GP-04026 x Entr } \\
\text { no.-20 }\end{array}$ & & $-95.02 *$ & -97.45 & $-86.52 * *$ & $-93.27 * *$ & $81.49 * *$ & 0.00 & $208.50 * *$ & $80.49 * *$ \\
\hline $\begin{array}{l}\mathrm{HE} \\
19\end{array}$ & $\begin{array}{l}\text { GP-01009 } \\
\text { GP-01005 }\end{array}$ & $\mathrm{x}$ & 69.16 & 60.64 & $-87.58 * *$ & $18.44 * *$ & 0.00 & 3.46 & 39.53 & 30.74 \\
\hline $\begin{array}{l}\mathrm{HE} \\
20\end{array}$ & $\begin{array}{l}\text { GP-01009 } \\
\text { GP-01004 }\end{array}$ & $\mathrm{x}$ & 41.68 & 26.02 & 39.70 & $38.14 * *$ & -0.67 & -1.00 & 43.09 & 33.94 \\
\hline $\begin{array}{l}\mathrm{HE} \\
21\end{array}$ & $\begin{array}{l}\text { GP-01009 } \\
\text { BHAC-04038(1) }\end{array}$ & $\mathrm{x}$ & 26.58 & 6.57 & 39.05 & $-7.92 * *$ & 0.33 & 0.00 & 46.09 & 42.37 \\
\hline $\begin{array}{l}\mathrm{HE} \\
22\end{array}$ & $\begin{array}{l}\text { GP-01009 x Entr } \\
\text { no.-20 }\end{array}$ & & 19.94 & -85.3 & -2.85 & $-32.35 * *$ & 2.56 & -1.01 & 65.98 & $62.60 *$ \\
\hline $\begin{array}{l}\mathrm{HE} \\
23\end{array}$ & $\begin{array}{l}\text { GP-01005 } \\
\text { GP-01004 }\end{array}$ & $\mathrm{x}$ & 15.93 & -1.43 & -22.53 & $-25.72 * *$ & -0.00 & -0.33 & -30.42 & -30.83 \\
\hline $\begin{array}{l}\mathrm{HE} \\
24\end{array}$ & $\begin{array}{l}\text { GP-01005 } \\
\text { BHAC-04038(1) }\end{array}$ & $\mathrm{x}$ & $41 . .47$ & 14.24 & -11.92 & $-12.46 * *$ & -1.67 & -2.00 & $53.85^{*}$ & 40.74 \\
\hline $\begin{array}{l}\mathrm{HE} \\
25\end{array}$ & $\begin{array}{l}\text { GP-01005 x Entr } \\
\text { no.-20 }\end{array}$ & & 79.76 & 32.33 & 7.88 & $-5.77 * *$ & 1.19 & -0.34 & $86.43^{* *}$ & $78.15 * *$ \\
\hline $\begin{array}{l}\mathrm{HE} \\
26\end{array}$ & $\begin{array}{l}\text { GP-01004 } \\
\text { BHAC-04038(1) }\end{array}$ & $\mathrm{x}$ & -10.00 & -15.49 & 24.04 & $80.00 * *$ & -3.00 & -3.00 & 17.04 & 6.50 \\
\hline $\mathrm{HE}$ & GP-01004 x Entr & & -12.85 & -27.04 & -1.99 & $-13.93 * *$ & -1.53 & -3.33 & 18.25 & 12.35 \\
\hline
\end{tabular}




\section{MInstitute Macrothink}

\begin{tabular}{|c|c|c|c|c|c|c|c|c|c|}
\hline $\begin{array}{l}27 \\
\mathrm{HE} \\
28\end{array}$ & $\begin{array}{l}\text { no. }-20 \\
\text { BHAC-04038(1) } \quad \mathrm{x} \\
\text { Entry no.-20 }\end{array}$ & -9.72 & -20.19 & -7.81 & $15.48 * *$ & 1.19 & -0.67 & 40.85 & 34.55 \\
\hline & Minimum & -95 & -97 & -87 & -93 & -77 & -88 & -79 & -89 \\
\hline & Maximum & 658 & 290 & 95 & 93 & 81 & 7 & 253 & 110 \\
\hline & $\begin{array}{l}\text { Number of }+ \text { ve } \\
\text { significant heterosis }\end{array}$ & 12 & 8 & 12 & 8 & 5 & 0 & 6 & 6 \\
\hline & $\begin{array}{l}\text { Number of - ve } \\
\text { significant heterosis }\end{array}$ & 4 & 4 & 3 & 10 & 10 & 11 & 0 & 9 \\
\hline
\end{tabular}

$* \& * *$ Significant at $5 \%$ and $1 \%$ levels, respectively.

\subsubsection{Stem Diameter}

Mid parent and better parent heterosis ranged from -173 (HE9) to 81 (HE18) and -88 (HE12) to 7.16 (HE8), respectively. Among the 28 cross combinations, five crosses recorded significant positive heterosis over mid parent and none of the crosses was found significant over better parent, respectively. While ten and eleven crosses recorded significant negative heterotic effects over mid parent and better parent, respectively. The cross combinations HE18, HE17, HE16, HE15 and HE14 showed significant positive mid parent heterosis for stem diameter. These results are in accordance with the results of Rathi et al. (2016) and Rahman et al. (2006). Significant negative heterosis showed by the crosses HE12, HE9, HE10, HE7, HE6, Entry P-S-2 x GP-01004, HE13, HE4, HE3, HE11 and HE12, HE9, HE7, HE5,HE10, HE4, HE6, HE13, HE3, HE11, HE14 for mid parent and better parent, respectively.

\subsubsection{Head Diameter}

Mid parent and better parent heterosis ranged from -79.12 (HE5) to 253.59 (HE17) and -88.72 (HE5) to 109.82 (HE17), respectively (Table 1). Among the 28 cross combinations, six crosses recorded significant positive heterosis over both mid parent and better parent, respectively. Nine crosses recorded significant negative heterotic effects over better parent. The cross combinations HE17, HE18, HE16, HE15, HE25 and HE24 showed significant positive mid parent heterosis and the crosses HE17, HE18, HE16, HE15, HE25 and HE24 showed significant positive better parent heterosis for stem diameter. These results are in accordance with the results of Jan et al. (2009), Rahman et al. (2006), Chavan (2013), Dhillon and Tyagi (2016), Reddy and Nadaf (2013), Encheva et al. (2015) and Amin et al. (2014).

\subsubsection{Number of Seeds per Head}

The heterosis over mid parent and better parent ranged from -98 (HE7) to 148 (HE15) and -99 (HE7) to 26 (HE15), respectively. Significant positive heterosis over mid parent was recorded in 12 cross combinations (up to 148\%) and heterosis over better parent in three crosses (up to 26\%). While 11 crosses showed significant negative heterosis over mid and better parent. The cross combination HE15, HE17, HE16, HE18, HE14, HE19, HE24, HE28, HE23, HE25, HE20 and HE27 showed significant positive mid parent heterosis and the crosses HE15, HE17and HE19 showed significant positive better parent heterosis for number of seeds per head. The findings of the present research are in accordance with the results reported by Habib et al. (2006) and Hladni (2015). Significant negative heterosis over mid parent was found in the crosses HE7, HE2, HE3, HE5, HE4, HE13, HE9, HE11, HE10, HE12, 
HE26 and better parent heterosis in the crosses HE7, HE6, HE3, HE5, HE4, HE9, HE11, HE10, HE14.

\subsubsection{Seed Weight per Head (g)}

Mid parent and better parent heterosis ranged from -88 (HE14) to 441.71 (HE3) and -94 (HE14) to 184 (HE3), respectively. Yamagar et al. (2015) reported mid parent (MP) ranging from 33 to 148 better parents (BP) ranged from 3 to 121. Significant positive mid parent heterosis were recorded in 12 crosses and heterobeltiosis in 11 crosses. Significant negative heterobeltiosis was recorded in five crosses. The cross combinations HE3, HE5, HE4, HE11, HE10, HE9, HE6, HE8, HE13, HE7, HE12, HE2 showed significant positive mid parent heterosis and the crosses HE3, HE5, HE4, HE8, HE11, HE10, HE9, HE2, HE6, HE7, HE13 showed significant positive better parent heterosis for seed weight per head. These results are in accordance with the findings reported by Meena et al. (2013), Sujatha and Reddy (2009), Rathi et al. (2016). Significant negative better parent heterosis was observed by the crosses HE16, HE17, HE18, HE14 and HE15.

\subsubsection{Seed Weight $(\mathrm{g})$}

Mid parent and better parent heterosis ranged from -80 (HE15) to 375 (HE3) and 89 (HE15) to 157 (HE3), respectively (Table 3). Among the 28 cross combinations, 11 crosses gave significant positive mid parent heterosis and nine crosses gave heterobeltiosis. Significant negative heterobeltiosis was observed in four crosses. The cross combinations HE5, HE11, HE9, HE6, HE13, HE10, HE4, HE7, HE8, HE2, HE12 showed significant positive mid parent heterosis and the crosses HE5, HE11, HE9, HE8, HE2, HE6, HE13, HE4, HE10 showed significant positive better parent heterosis for the trait 100 seed weight. Amin et al. (2014), Chavan (2013) agreed with the findings of positive heterosis. Rahman et al. (2006) reported $463.6 \%$ hetrobeltiosis for 100 seed weight. Significant negative mid parent and better parent heterosis was observed by the crosses HE15, HE16, HE17, HE18 and HE18, HE17, HE16, HE14 for 100 seed weight.

\subsubsection{Seed Yield per Plant}

Positive heterosis for seed yield per plot is an important aspect for the improvement of seed yield in sunflower.

Table 3. Heterosis over mid parent and better parent for number of seed per head, seed weight per head, 100 seed weight and seed yield per plot in sunflower

\begin{tabular}{llcccccc}
\hline \multirow{2}{*}{$\begin{array}{l}\text { S1. } \\
\text { No. }\end{array}$} & Crosses & \multicolumn{2}{c}{ Number of seed per head } & \multicolumn{2}{c}{100 seed weight $(\mathrm{g})$} & \multicolumn{2}{c}{ Seed yield per plant $(\mathrm{g})$} \\
\cline { 3 - 8 } & & & & & & & \\
& & Mid & Better & Mid & Better & Mid & Better \\
& & -79.39 & -88.63 & -3.55 & -11.22 & 14.96 & 2.86 \\
\hline 1 & Entry P-S-2 x Entry-23 & -76.59 & -87.13 & $110.87^{* *}$ & $93.23^{* *}$ & 9.15 & -6.19 \\
2 & Entry P-S-2 x GP-04026 & $-97.62^{* *}$ & $-98.68^{* *}$ & 375.56 & 156.77 & $-92.13^{*}$ & $-95.91^{* *}$ \\
3 & Entry P-S-2 x GP-01009 & $-97.50^{* *}$ & $-98.60^{* *}$ & $180.44^{* *}$ & $54.38^{* *}$ & $-96.16^{* *}$ & $-98.03^{* *}$ \\
4 & Entry P-S-2 x GP-01005 & & parent & parent & parent & parent &
\end{tabular}




\begin{tabular}{|c|c|c|c|c|c|c|c|}
\hline 5 & Entry P-S-2 x GP-01004 & $-97.54 * *$ & $-98.63 * *$ & $333.77 * *$ & $133.86 * *$ & $-93.77 * *$ & $-96.81 * *$ \\
\hline 6 & Entry P-S-2 x BHAC-04038(1) & $-97.77 * *$ & $-98.76^{* *}$ & $202.10 * *$ & $64.74 * *$ & $-91.67 *$ & $-95.68 * *$ \\
\hline 7 & Entry P-S-2 x Entry no.-20 & $-98.05 * *$ & $-98.92 * *$ & $148.51 * *$ & 33.27 & $-95.62 * *$ & $-97.77 * *$ \\
\hline 8 & Entry-23 x GP-04026 & 22.79 & 20.14 & $128.57 * *$ & $94.30 * *$ & -12.53 & -16.44 \\
\hline 9 & Entry-23 x GP-01009 & $-97.17 * *$ & $-98.57 * *$ & $294.29 * *$ & $110.39 * *$ & $-88.71 *$ & $-94.08 * *$ \\
\hline 10 & Entry-23 x GP-01005 & $-96.76^{* *}$ & $-98.36^{* *}$ & $180.99 * *$ & $52.43 * *$ & $-95.54 * *$ & $-97.71 * *$ \\
\hline 11 & Entry-23 x GP-01004 & $-97.15^{* *}$ & $-98.56^{* *}$ & $301.70 * *$ & $114.07 * *$ & $-93.63 * *$ & $-96.71 * *$ \\
\hline 12 & Entry-23 x BHAC-04038(1) & $-91.04 * *$ & $-95.46 * *$ & $103.27 * *$ & 9.38 & $-92.54 *$ & $-96.10 * *$ \\
\hline 13 & Entry-23 x Entry no.-20 & $-97.22 * *$ & $-98.60 * *$ & $199.02 * *$ & $58.63 * *$ & $-93.80 * *$ & $-96.82 * *$ \\
\hline 14 & GP-04026xGP-01009 & $30.14 *$ & $-34.20 * *$ & -62.93 & $-79.69 * *$ & $199.45^{* *}$ & $57.70^{*}$ \\
\hline 15 & GP-04026 x GP-01005 & $148.40^{* *}$ & $25.72 * *$ & $-79.94 *$ & -88.79 & $193.94 * *$ & $51.66 * *$ \\
\hline 16 & GP-04026 x GP-01004 & $131.31 * *$ & 16.94 & $-77.52 *$ & $-87.70 * *$ & $221.57 * *$ & $66.44 * *$ \\
\hline 17 & GP-04026 x BHAC-04038(1) & $145.79 * *$ & $24.30 * *$ & $-79.37 *$ & $-88.56^{* *}$ & $358.67 * *$ & $141.06 * *$ \\
\hline 18 & GP-04026 x Entry no.-20 & $111.51 * *$ & 6.48 & $-79.05^{*}$ & $-88.61 * *$ & $161.95 * *$ & $34.59 * *$ \\
\hline 19 & GP-01009 x GP-01005 & $23.48 * *$ & $17.97 *$ & 13.88 & 1.97 & $72.73 * *$ & $38.09 * *$ \\
\hline 20 & GP-01009 x GP-01004 & $16.04 *$ & 15.69 & 31.23 & 29.93 & $55.55^{*}$ & 29.18 \\
\hline 21 & GP-01009 x BHAC-04038(1) & 11.66 & 10.37 & 11.92 & 5.27 & $142.47 * *$ & $137.66^{* *}$ \\
\hline 22 & GP-01009 x Entry no.-20 & -2.98 & -6.92 & 5.10 & 0.25 & 70.41 & 29.18 \\
\hline 23 & GP-01005 x GP-01004 & $18.94 *$ & 13.30 & 15.33 & 2.37 & $52.12 * *$ & $44.97 * *$ \\
\hline 24 & GP-01005 x BHAC-04038(1) & $19.48 *$ & 15.44 & 3.53 & -1.78 & $94.25 * *$ & $57.70 * *$ \\
\hline 25 & GP-01005 x Entry no.-20 & $16.56 *$ & 7.05 & 14.121 & -1.97 & $69.65 * *$ & $58.30 * *$ \\
\hline 26 & GP-01004 x BHAC-04038(1) & $-15.85^{*}$ & -17.08 & -4.72 & -11.21 & $-38.64 *$ & $-48.20 * *$ \\
\hline 27 & GP-01004 x Entry no.-20 & $10.42 *$ & 6.25 & 26.02 & 21.37 & $59.68 * *$ & $42.50 * *$ \\
\hline 28 & BHAC-04038(1) $\quad$ x $\quad$ Entry & $19.12 *$ & 13.01 & 26.74 & 14.07 & $63.85 * *$ & $26.18 *$ \\
\hline & no. -20 & & & & & & \\
\hline & Minimum & -98 & -99 & -80 & -89 & -97 & -98 \\
\hline & Maximum & 148 & 26 & 376 & 157 & 359 & 141 \\
\hline & $\begin{array}{l}\text { Number of }+ \text { ve significant } \\
\text { heterosis }\end{array}$ & 12 & 3 & 11 & 9 & 13 & 12 \\
\hline & $\begin{array}{l}\text { Number of - ve significant } \\
\text { heterosis }\end{array}$ & 11 & 11 & 4 & 4 & 11 & 11 \\
\hline
\end{tabular}

$* \& * *$ Significant at $5 \%$ and $1 \%$ levels, respectively.

The heterotic value over mid and better parent for seed yield per plant ranged from -97 (HE4) to 359 (HE17) and -98 (HE4) to 141 (HE17), respectively. Out of 28 crosses, 13 crosses exhibited positive significant mid parent heterosis and 12 crosses exhibited better parent heterosis, respectively. The crosses HE17 showed the highest significant positive heterosis over mid parent followed by HE16, HE14, HE15, HE18, HE21, HE24, HE19, 

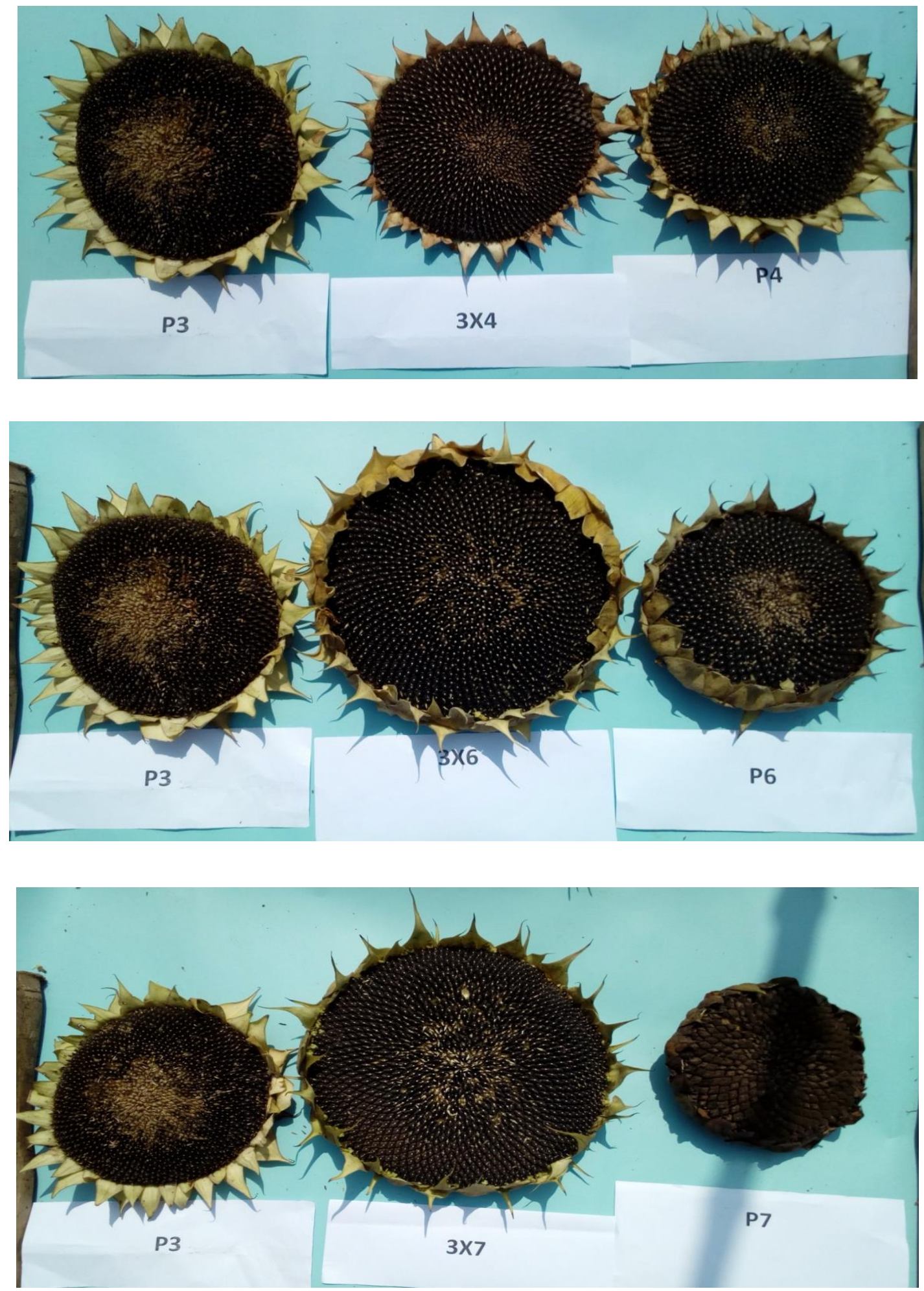

Plate 2. Head size of selected hybrid and parent. Here, 3= GP-04026, 4= GP-01009, 6= GP-01004, $7=$ BHAC $-04038(1)$

HE25, HE28, HE27, HE20 and HE23. The cross combination HE17showed the maximum significant positive heterosis over better parent for seed yield per plant followed by HE18, 


\section{MInstitute Macrothink $_{\text {Int }}$}

HE21, HE16, HE14, HE15, HE25, HE24, HE23, HE27, HE19. High positive heterosis was reported by Thombare et al. (2007), Chavan (2013), Neelima (2013), Reddy and Nadaf (2013), Encheva and Penchev (2015), Encheva et al. (2015), Amin et al. (2014), Archana and Thorat (2017) for seed yield in sunflower.

\subsection{Heritability}

Significant difference was observed among the inbreds which used for crossing in half diallel fashion for the character days to maturity, plant height, head diameter, number of seed per head and for seed yield/plant. Genotypic coefficient of variation and phenotypic coefficient of variation were close to each other for the character days to maturity, plant height, stem diameter and for seed yield per plant which indicate additive gene action. High heritability found for the characters days to maturity, plant height, stem diameter and for seed yield/plant.

Table 4. Estimation of genetic components of seven yields related characters in sunflower

\begin{tabular}{lccccccc}
\hline Component & DM & PH $(\mathrm{cm})$ & HD $(\mathrm{cm})$ & SD $(\mathrm{cm})$ & NS & $\begin{array}{c}\text { 100SW } \\
(\mathrm{g})\end{array}$ & $\begin{array}{c}\text { Seed } \\
\text { yield/Plant }\end{array}$ \\
\hline Range & $90-101$ & $48.29-137.67$ & $6.86-17.87$ & $1.12-2.27$ & $37-250$ & $2.23-21.42$ & $30.23-541.20$ \\
Mean & 96 & 97.25 & 13.23 & 1.60 & 118.81 & 10.58 & 266.65 \\
$\sigma^{2} \mathrm{~g}$ & 10.29 & 445.41 & 2.98 & 0.10 & 2161.96 & 60.185 & 24251.42 \\
$\sigma^{2} \mathrm{p}$ & 13.15 & 481.58 & 6.92 & 1.24 & 3134.74 & 233.61 & 26421.93 \\
$\mathrm{GCV}$ & 3.34 & 21.70 & 13.07 & 13.55 & 39.13 & 66.95 & 58.40 \\
$\mathrm{PCV}$ & 3.78 & 22.56 & 19.90 & 15.69 & 47.12 & 90.22 & 60.96 \\
$\mathrm{~h}^{2}(\%)$ & 78.25 & 92.49 & 43.15 & 74.60 & 68.97 & 55.05 & 91.78 \\
$\mathrm{~F}-\mathrm{value}$ & $* *$ & $* *$ & $*$ & - & $* *$ & - & $* *$ \\
$\mathrm{CV} \%$ & 3.04 & 10.71 & 25.98 & 14.96 & 45.43 & 60.48 & 30.26 \\
\hline
\end{tabular}

$\mathrm{DM}=$ Days to maturity, $\mathrm{PH}=$ Plant height $(\mathrm{cm}), \mathrm{HD}=$ head diameter $(\mathrm{cm}), \mathrm{SD}=$ Stem diameter $(\mathrm{cm})$, $\mathrm{NS}=$ Number of seed per head, $\mathrm{SW}=$ Seed weight per head, $\mathrm{r}_{\mathrm{g}}=$ Genotypic correlation, $\mathrm{r}_{\mathrm{p}}=$ Phenotypic correlation, $* *=$ Significant at $1 \%$ level, $*=$ Significant at $5 \%$ level.

\section{Conclusion}

High heritability along with significant mid parent and better parent heterosis indicate scope of utilization of hybrid as commercial and further use in breeding programmes. Several outstanding cross combinations, HE17(P3 x P7), HE16 (P3 x P6), HE14 (P3 x P4), HE15 (P3 x P5), and HE18 (P3 x P8) showed significant and desirable heterosis for seed yield per plant over mid parent and better parent. The hybrid combinations HE17, HE16 and HE14 could be utilized to exploit the heterosis as well as commercial multiplication of seed to get direct benefit by the farmers.

\section{References}

Amin, E. S. A., Mohamed, Y. M., Abubaker, A., \& Abdallah (2014). Gene effects and heterosis in sunflower (Helianthus annuus L.) Agricultural Science Research Journal, 5(4), 57-61.

Anonymous (2018). Report on Bangladesh Sample Vital Statistics-2018. Monitoring the 
Situation of Vital Statistics of Bangladesh (MSVSB) 2nd Phase Project Bangladesh Bureau of Statistics. Ministry of Agriculture. Bangladesh. P-1.

Anonymous (2019a). Krishi Dairy 2019, Department of Agricultural Extension, Ministry of Agriculture, Dhaka, Bangladesh. P-14.

Archana, W., Thorat, E. R., Vaidya, S., Gahukar, J., \& Sakkhare, S. B. (2017) Estimation of heterosis in newly developed sunflower hyybrids (Helianthus annuus L.). Trends in Biosciences, 10(31), 6602-6607.

Chavan, B. H. (2013). Heterosis and combining ability studies in sunflower (Helianthus annuus L.) (Doctoral Dissertation, Mahatma Phule Krishi Vidyapeeth, Rahuri).

Dhillon, S. K., \& Tyagi, V. (2016). Combining ability studies for development of new sunflower hybrids based on diverse cytoplasmic sources. Helia, 39(64), 71-80. https://doi.org/10.1515/helia-2015-0005

Encheva, J., \& Penchev, E. (2015). Heterosis for agronomical important traits in sunflower hybrid Rada developed with mutant restorer line 12002 R. Helia, 38(62), 93-108. https://doi.org/10.1515/helia-2014-0027

Fonseca, S., \& Peterson, F. L. (1968). Hybrid vigour in a seven parents diallel crosses in common winter wheat (Triticum aestivum L.). Crop Science, 8(1), 85-88. https://doi.org/10.2135/cropsci1968.0011183X000800010025x

Heiser, C. B. (1976). The Sunflower, University of Oklahoma Press. Norman, UK.

Mallik, M. S. A. (2013). Quality seed production of oilseed crop: An overview. Paper presented in workshop on Modern Techniques for Quality Seed Production of Oilseed Crops. Oilseed Research Centre, Bangladesh Agricultural Research Institute. Gazipur. October 02, 2013. P. 18-26.

Meena, C. R., Meena, H. P., \& Sinha, B. (2013). Fertility restoration, combining ability effects and heterosis in sunflower (Helianthus annuus L.) using different CMS sources. Journal of Oilseeds Research, 30(1), 60-64.

Neelima, S. (2013). Estimation of standard heterosis in sunflower hybrids. Karnataka Journal of Agricultural Science, 26(3), 415-416.

Rahman, D. H., Khalil., I. H., Farooqi, A., \& Habib, R. (2006). Magnitude of heterosis for morphological and yield traits in sunflower. (Helianthus annuus L.) Pakistan Journal of Plant Science, 12(1), 55-64.

Rahman, L. (2009). Advances in Oilseed Research in Bangladesh. Proceedings of the National Workshop on Research and Development of Oilseed Crops in Bangladesh and Future Challenges Ahead. 29-30 April. pp. 1-15. BARI, Gazipur, Bangladesh.

Rathi, S. R., Nichal, S. S., Vaidya, E. R., Wandhare, M. R., \& Janjal, S. M. (2016). Heterosis for yield, its components and oil content in sunflower (Helianthus annuus L.). International Journal of Tropical Agriculture, 34(4), 1063-1072. 


\section{Macrothink}

Journal of Agricultural Studies

ISSN 2166-0379 2021, Vol. 9, No. 1

Reddy, V. R. P., \& Nadaf, H. L. (2013). Exploitation of heterosis in sunflower (Helianthus annuus L.). Trends in Bioscience, 6(5), 762-769.

Sujatha, M., \& Reddy, A. V. (2009). Heterosis and combining ability for seed yield and other yield contributing characters in sunflower, Helianthus annuus L. Journal of Oilseeds Research, 26(1), 21-31.

Thombare, V., Makane, V. G., \& Borgaonkar, S. B. (2007). Combining ability studies in sunflower. Internet Journal of Plant Science, (2), 133-136.

Turner, J. H. (1953). A study of heterosis in upland cotton, combining ability and inbreeding effects. Agronomy Journal, 45, 487-490.

https://doi.org/10.2134/agronj1953.00021962004500100008x

Yamagar, S. V., Ghodake, M. K., \& Mali, D. R. D. (2015). Estimation of heterosis for yield and yield contributing characters in sunflower (Helianthus annuus L.), 10(4), 1991-1996.

\section{Copyright Disclaimer}

Copyright for this article is retained by the author(s), with first publication rights granted to the journal.

This is an open-access article distributed under the terms and conditions of the Creative Commons Attribution license (http://creativecommons.org/licenses/by/4.0/). 